\title{
Promišljanja o čovjeku kao biću dinamičko- dijalektičke napetosti u nekim djelima Romana Guardinija
}

\author{
Davor Šimunec*
}

\begin{abstract}
Sažetak
U radu se nastoji osvijetliti specifičnost Guardinijeva dijalektičkog mišljenja o čovjeku, kojeg on razumijeva kao biće koje dozrijeva ili se ostvaruje kao autentična osoba ukoliko uspijeva uspostaviti adekvatnu mjeru u oscilacijama polarnosti kroz njegove duhovne $i$ tjelesne te unutar-individualne $i$ vanjske društvene dimenzije samoga sebe. U cilju razotkrivanja te dijalektičke niti koja bi se protezala kroz sve bitne dimenzije ljudskog »ja«, na početku se iznosi način na koji Guardini uopće misli o dijalektičkom ustroju stvarnosti, da bi se nadalje smjeralo konkretizaciji te iste dijalektičnosti u primjerima koji se tiču »strukture « čovjeka i njegovih individualno-socijalno-razvojnih sposobnosti. Tako se obraduju polarni momenti u odnosima duše i tijela, slojeva ljudske osobe, kao i u osnovnim crtama, razvojna dinamika ljudskog dozrijevanja od djetinjstva do odrasle dobi. Na kraju se govori o krepostima kao duhovnim vrijednostima koje upućuju na razvoj onih sposobnosti s kojima bi se s jedne strane omogućilo čovjekovo unutarnje $i$ vanjsko uravnoteženje, kao i, s druge strane, otvorenost prema Apsolutu.

Ključne riječi: dijalektika, polarna opozicija, duša, tijelo, osoba, životno dozrijevanje, kreposti
\end{abstract}

\section{Uvod}

U ovom članku usredotočujem se samo na pojedine crte dijalektičkoantropološkog mišljenja u pojedinim djelima Romana Guardinija, nastojeći iz njih razotkriti dimenzije dijalektičkog obilježja čovjeka kao bića polarnih napetosti. Stoga već u prvom poglavlju sumarno pokazujem kako to uopće Guardini promišlja dijalektično o stvarnosti uopće, s obzirom na njegov govor o polarnim suprotnostima. U drugom i trećem poglavlju konkretno zahvaćam čovjekove strukturne dimenzije u govoru, koje se tiču odnosa duhovnoga i tjelesnoga kao i samih slojeva osobe. U četvrtom poglavlju nastojim otkriti što bi to bilo dijalek-

* Davor Šimunec, Katolički bogoslovni fakultet Sveučilišta u Zagrebu. Adresa: Vlaška 38, p.p. 432, 10001 Zagreb, Hrvatska. E-pošta: dav.simun@gmail.com 
tično u dozrijevanju čovjeka. Zadnjim se poglavljem želi na veoma sažet način uočiti pozitivna i na neki način dijalektična uloga kreposti, kojima se čovjek može uravnotežiti kao cjelovito unutarnje i vanjsko biće. Valja dodati kako se ovim člankom ne ide toliko u širinu same teme u smislu da se želi iscrpiti svekolika Guardinijeva antropološka misao, što bi ovdje bilo nemoguće i nepotrebno, nego se samo pokušava na temelju pojedinih njegovih djela iščitati dijalektički karakter čovjeka kao polarnog bića jedinstva i ravnoteže.

\section{Dijalektički ustroj stvarnosti}

O općenitom promišljanju stvarnosti, mimo kakvih god suhih ili možda jalovih spekulacija kojima bi se odozgo deduktivno ili posve apstraktno htjelo izvoditi zaključke o univerzumu svijeta i čovjeka, Guardini se želi više zanimati za konkretnu sferu odozdo, misleći o njoj na način kako se ona već pokazuje u svojoj pokretno-oscilirajućoj egzistenciji, kao da bi uvijek bila izmjenično sastavljena od dinamičkog i statičkog momenta, koji bi u konačnici težili nužnomu uravnoteženju cjelovitosti sebe u smislu neke stvari ili bića. ${ }^{1}$ Već svojim djelom iz 1925. godine, napisanim na njemačkom jeziku pod naslovom Der Gegensatz : Versuche zu einer Philosophie des Lebending-Konkreten, u kojem polazi od temeljnog pitanja što zapravo stvarnost jest na način kako ona funkcionira na razini vlastite konkretnosti i ljudske egzistencije, Guardini zaključuje da bi ista dijalektički stalno bila uvučena, sumarno rečeno, u sapetim odnosima raznih suprotnih polarnosti zbilje. ${ }^{2}$

1 Srž Guardinijeva dijalektičkog mišljenja leži u promoviranju ideje polarne suprotnosti, koju on naime crpi iz svijeta fizike, gdje se, primjerice, govori o recipročnoj tenziji polova u vezi s energetskim poljima ili magnetizmom. Usp. Guido Sommavilla, Uvod, u: Scritti filosofici, Milano, 1964, 16. Polazeći od konkretnoga, u nastojanju za odgonetavanjem koje bi se svodilo na pitanje, što je to stvarnost uopće, ono heurističko za Guardinija moralo bi se nekako stopiti s ontološkim. Usp. Enrico Santini, Esistenza ed opposizione. Ermeneutica della libertà in Romano Guardini, Roma, 1994, 96.

2 Ovdje koristim samo talijanski prijevod djela: Romano Guardini, L'opposizione polare: Saggio per una filosofia del concreto vivente, Brescia, 1997. (Prijevod na osnovu prvog izdanja na njemačkom: Der Gegensatz: Versuche zu einer Philosophie des Lebending-Konkreten, Mainz, 1925.). U nastojanju za dijalektičkim shvaćanjem zbilje, Guardini često pokušava, mimo kakvih god rigidnih monizama ili dualizama, izabirati srednji put mišljenja, varirajući, s jedne strane, između sirove empiričnosti pojavâ i, s druge strane, suhe apstraktnosti u donošenju sudova o nečemu. Usp. Giuseppe d'Acunto, Concreteza e opposizione in Guardini, u: Información Filosófica, 8 (2011) 17, 107-120. Teolog i liturgičar Ivica Žižić napomenuo je kako »Guardini njeguje specifičnu onto-fenomenološku misao, otvorenu konkretno-živućemu (Lebendig-Konkret). Sav njegov interes za formu [liturgiju, op. a.] u stvarnosti jest nastojanje da se dosegne prikladan dijalektički, inkluzivni model koji će izmaći zamkama reduktivnoga idealizma s jedne, i pozitivizma s druge strane. Teorijski temelj tom poduhvatu Guardini je osigurao u svojem prvom važnom filozofskoepistemološkom eseju Polarne suprotnosti iz 1914. godine [...] u kojem je razradio fenomenološki i gnoseološki model spoznaje te osigurao solidne temelje za njegovu primjenu u najrazličitijim sferama svijeta života: od liturgije, teologije pa sve do književnosti i filozofije religije «. Ivica Žižić, Liturgija kao umjetnost i igra kod Romana Guardinia, u: Diacovensia 23 (2015.) 3, 295. U ovom ću poglavlju veoma sažeto navesti samo primjere triju polarnih opozicija. 
Njegova ideja o polarnoj suprotnosti, crpljena iz zamjedbe iskustveno-životne stvarnosti da oscilacija doista postoji u mnogim varijacijama polarnih napetosti u sferi čovjeka ili svijeta, osobito bi dolazila do izražaja u primjeru odnosa forme i punine kao međusobno u-parenih suprotnosti. ${ }^{3}$ Jer, dok bi u tom slučaju s jedne strane život po sebi već podrazumijevao fluentnu težnju prema bogatomu repertoaru mogućnosti za ovakvim ili onakvim ispunjenjima i bujnostima doživljaja, spoznajâ i izričaja (ako je riječ o čovjeku), s druge strane to isto moralo bi kadtad radi vlastitog opstanka i održanja biti o-formljeno, na neki način »strpano « u oblik, a nasuprot kaosu. ${ }^{4}$ Sâm ce život, stoga, tražiti formu kao disciplinu, figuru i zakon, kao nešto što zahtijeva red, elaboraciju, konfiguraciju, regulaciju i umovanje. Karakter takvih oscilacija očituje se prije svega u obrnuto razmjernom odnosu dvaju polova: primjerice smjeranje prema sve većoj punini simultano bi slabilo formu koja bi uvijek težila formaliziranju, tako i obrnuto, formalnost i formativnost forme, opet bi limitirala, usmjeravala i regulirala očitovanje neke težnje prema ispunjenju nečega. ${ }^{5}$ I nešto slično u slučaju odnosa akta i strukture, dok bi se ovim prvim polom sugerirala životnost koja već po sebi upućuje na razne procese aktivnosti, protočnosti, rasta, razvoja i kontinuitet mijena, kako na biološko-fiziološkoj tako i na psihološko-društvenoj razini, a da se ti isti procesi ne bi samo tako rasplinuli u bez-svrhovitost, morat će pridoći i drugi nasuprotni momenti stabilne strukturacije nečega, primjerice kroz činjenicu psihosomatske strukture ljudskog tijela ili određenog stupnja karakterne strukture kao uvjeta aktualizacije kakvih god djelotvornih aktivnosti ili smjeranja bića. ${ }^{6}$ Struktura bi tako upućivala na auto-prezentaciju ukupnosti ili cjelovitosti sebe, zakone vlastite sastavljenosti i odvijanja procesa, također i mjeru energijâ, dubinâ i širinâ bioloških, psiholoških i društvenih determinanata po čijim se koordinatama tek nešto može dogoditi. ${ }^{7}$ Spomenimo ovdje i pol produkcije, primjerice u pothvatu neke umjetničke ili tehničke kreacije odnosno inovacije, koja se opet može aktualizirati samo ako proizlazi ili se kreće u uvjetima protimbe vlastite dispozicije kao potencijala koji stvaralačkoj snazi pridjeva energiju, organizacijski i koordinacijski smjer. ${ }^{8}$ To pak znači da kreacija, osim kod Boga, u drugim slučajevima ne može biti izvedena ex nihilo, jer one moći koje spadaju na čovjekov stvaralački svijet mogu samo računati na derivaciju ili možda asocirajući na sirovu materijalnu stvarnost, na re-produkciju nečega, jer se nešto samo može izvoditi iz postojećih polazišta dispozicijâ. ${ }^{9}$

3 Usp. Romano Guardini, L'opposizione polare, str. 46.

4 Guardini u svojem djelu često kombinira područja općenite fizikalno-biološke stvarnosti s onima koja se odnose na čovjeka.

5 Usp. Isto, str. 47-48.

6 Usp. Isto, str. 34-37, 52-53.

7 Usp. Isto, str. 38.

8 Usp. Isto, str. 65-67.

9 Iako bi kreacija u svojem autentičnom značenju htjela sebi pripisivati neuvjetovanu spontanost u pri-donošenju nečega novoga (u umjetničkom ili nekom drugom smislu), čovjek kao kreator opet je uvjetovan utjecajem primjerice kulturnog ozračja u kojem živi i razvija se ili nekim drugim okolnostima koje ga potiču da bude na neki način kreator. Usp. Isto, str. 60-61. 
Treba dodati kako za razliku od Hegelovog dijalektičkog mišljenja, gdje se teza i antiteza međusobno prevladavaju u suprotnostima odnosno dokidaju u sintezi (kao negaciji negacije) smjerajući prema jednom višem jedinstvu, Guardinijev govor o polaritetima ne sugerira mogućnost njihove asimilacije u nešto treće novo kao sintetičko, kao što ni ti isti polovi nisu opet toliko međusobno kontradiktorni koliko samo kontrarni. ${ }^{10}$ Polarnosti dakle ostaju takve kakve jesu bez ikakvog samodokidanja u dijalektičkoj igri sa sebi suprotnim polovima, težeći prije svega jedinstvu neke zbilje koja je takva u mjeri uspostave ravnoteže same sebe. Ipak, za našeg autora kategorija ravnoteže predstavlja nešto što iskustveno nije lako dohvatiti upravo zbog dijalektičkog usuda realnosti, koja se stalno iscrpljuje u dinamici polarnih oscilacija (barem što se čovjeka tiče), tragajući za vlastitom stabilizacijom i postignućem održivosti sebe. ${ }^{11}$

\section{Dijalektika duhovnog i tjelesnog}

Ako bi se spustili od općenitog ustroja stvarnosti pa sve do čovjeka samog, pitamo se što bi to u njemu konkretno bilo dijalektično? Budući da bi njega kao biće trebalo uzimati in toto, usprkos njegovoj uvijek prisutnoj egzistencijalnoj krizi u sapetosti prividnih protimbi »duhovnih«i »materijalnih « sastavnica, kako bi u tom smislu valjalo razumjeti primjerice pojmove »duše « $\mathrm{i} »$ tijela «? ${ }^{12} \mathrm{Za}$ Guardinija duša bi predstavljala ambijent živuće unutarnjosti bića »u kojemu sam ja sâm sa sobom samim« kao iznutrašnjeg momenta neke stabilnosti i sigurnosti, tj. kao »mojega središta, moje pričuve i mojega potpornja«, nešto što bi me osvješćivalo da »ja živim, rastem, spoznajem, odlučujem, stvaram, prihvaćam svoju odgovornost za sebe i za stvari koje ovise o meni« ${ }^{13}$ Ona bi upućivala na »unutarnjeg

10 Tu sam, međutim, izostavio izravno spominjanje i objašnjenje drugih polarnih suprotnosti zbog toga što bi to prelazilo okvire ovog rada. Stvarnost se tako može dodatno gledati i kroz odnose polova singularnosti i totalnosti, originalnosti i regule, imanentnosti i transcendentnosti, srodnosti i individuacije te jedinstva i pluralnosti. Usp. Isto, str. 25, 98-101 i 222.

11 Usp. Isto, str. 106-107. I teolog Ivica Raguž uočio je Guardinijevu sumnju oko postizanja neke zamislive idealne ravnoteže na unutarnjoj ili izvanjskoj osobno-ljudskoj razini, kojom bi se navodno dokinule polarne suprotnosti i njihove međusobne napetosti. Takva bi ravnoteža vodila statičnosti i umrtvljenosti, dok je sâm život po sebi upravo napetost i kretanje, ali uvijek u nekoj mjeri i ritmu. Usp. Ivica Raguž, Kršćanski — katolički svjetonazor prema Romanu Guardiniu, u: Diacovensia 23 (2015.) 3, 285-286. Ipak »mjera«i »ritam« već na neki način sugeriraju potrebu za uspostavom kakve-takve inter-i intra-personalne ravnoteže, bez koje čovjek ne može stabilno »funkcionirati« kao cjelovita osoba, o čemu će biti riječi u sljedećim poglavljima.

12 Po Eugenu Biseru, Guardini u svojim promišljanjima o čovjeku kao osobi vjerojatno crpi svoje nadahnuće od Platona i Aristotela i drugih antropoloških modela u prošlosti, koji su u ljudskom fenomenu uočavali razne stratume (primjerice tijelo-duša-duh) i razine između kojih se odvijaju napetosti koje bi trebale težiti nekoj harmonizaciji. Usp. Eugen Biser — Bohom Winfried Borghesi Massimo, Romano Guardini e la visione cristiana del mondo, Padova, 1989., 32-33.

13 Romano Guardini, L'uomo. Fondamenti di una antropologia cristiana, Brescia, 2009., str. 281. Iako naš autor u mnogim svojim djelima dotiče razne teme o čovjeku, u njegovim predavanjima zimskog semestra 1935./36. na Sveučilištu u Berlinu pod naslovom Der Mensch. Grundzüge einer christlichen Anthropologie, čiji prijevod na talijanskom koji sam već gore naveo ovdje koristim, sadržana je u najbitnijem smislu njegova kršćansko-antropološka sinteza govora o čovjeku. 
čovjeka «s obzirom na različitost te dimenzije u odnosu na izvanjskost pukoga tijela (Körper), koje kao takvo »ne donosi trag jedne takve produbljenosti, središnjosti i izvornosti«, ali ipak omogućava da se ne bi toliko trebalo sumnjati u to da ono ljudsko jednostavno jest u sebi »učvršćeno «biće duševno-tjelesnog složaja, dakle koje bi bilo uvijek nekako pri-sebi ili kod-sebe (ein eigentliches Bei-sich-selbstsein). ${ }^{14}$ Duša baš zato jer u sebi već uključuje neku duševnost koja je i duhovnog karaktera, usmjerena je već prema području »duha«. Ta duševnost koja je vazda pokretno-nemirna jer je ekscentrična i uvijek hoće ići prema nečemu većem, jer je uostalom i duhovna u potrebi transcendiranja osobito one bazične organskotjelesne očiglednosti sebe, teži dakle prema duhu kao nekomu idealu neslućenih mogućnosti, slobodâ i ispunjenja. Ali tu valja biti oprezan! Dok duša posjeduje karakter bliskosti, neposrednosti, snage i intimnosti zbog svoje povezanosti s tijelom, duh pak upućuje na distancu, udaljenost, uzdignutost i počesto hladnoću zbog svoje silne uzvišenosti nad prirodnim i običnim stvarima i bićima. ${ }^{15}$ Duh bi stoga na neki način podrazumijevao u svojim krajnjim konzekvencama ono što bi donekle bilo iznad-fenomenalnog ili s-onu-stranu-živućeg. ${ }^{16}$

Od pak pukog tijela (Körper) bića, na nešto višoj razini jest ono živuće tijelo (Leib) čovjeka, koje iako, posjedujući svojstva sensibilnosti i instinktivnosti (Trieb), u sebi uključuje i unutarnjost koju nazivamo dušom. ${ }^{17}$ Leib kao forma (Gestalt) predstavlja »statičku konstrukciju « $\mathrm{i}$ »dinamički sustav« procesa i pokretnosti, te pružajući svojevrsnu biološku bazu održanja i komunikacijske izražajnosti duše prema vanjskomu svijetu, može s njom ponekad zapasti i u odnose konflikata i disharmonije. ${ }^{18}$ Iz te složene »među-prožetosti« duševno-tjelesnog u čovjeku događa se na neki način dijalektička cirkulacija u odnosima njegovih unutarnjih i vanjskih sfera, jer »sve što se rađa i razvija od unutarnjosti prema izvanjskomu, hrani se i od izvanjskoga prema unutarnjemu ${ }^{19}{ }^{19}$ Kao što bi duša težila prema gore ili višemu u sferi duha, tako bi i tijelo bilo pritiskano opet prema dolje, onomu pukomu materijalnomu kao kemijsko-organskomu sadržaju sebe, zbog čega bi materija u svojoj krajnosti smjerala stanju vlastite puke tvarnosti, zbog čega bi, stoga, bila ispod-fenomenalno ili s-onu-stranu-mrtvog. ${ }^{20}$

U konačnici, po Guardiniju, čisti duh i čista materija predstavljaju dva nasuprotna pola između kojih oscilira ljudska egzistencija u napastima da se pokatkad čovjek osjeća više privučenim jednom ili drugom krajnošću, tj. da u njemu prevlada ona negativna obrnuta razmjernost duše i tijela, u kojoj bi svako

14 Isto. Usprkos tomu što bi po Guardiniju jedan materijalizam i biologizam negirao onaj osobni $d u h$ čovjeka koji nazivamo dušom, eliminiranjem te vrijednosti ljudske unutarnjosti negiralo bi se i samo ljudsko dostojanstvo. Usp. Romano Guardini, Etica, Brescia, 2003., 194-197.

15 Romano Guardini, L'uomo, str. 281.

16 Isto.

17 Isto, str. 282.

18 Isto.

19 Isto.

20 Isto. 
područje htjelo sebe proširiti na račun i protiv drugoga. ${ }^{21}$ Dok bi pak čisti duh mogao privlačiti nekoga prema zamišljaju mogućnosti apsolutne asimilacije sebe u isključivo duhovno područje, što bi bilo nemoguće zbog neodvojivosti od vlastite tjelesnosti, i opsesivna težnja prema nekoj čistoj materijalnosti u ljudskoj upravljenosti prema pukoj tjelesnosti — izložilo bi čovjeka riziku kaosa koji donosi onaj iracionalno-podsvjesno-instinktivni stratum bića (Trieb), ili bi ga zatvorilo u puke okvire bio-mehaničkog funkcioniranja tijela kao stroja. ${ }^{22}$ Jedinstvo duše i tijela (Einheit Seele-Lieb) na psihofizičkoj razini ljudske zbilje uključivao bi, dakle, neprestanu dijalektičku sapetost u nastojanju za »ritmom« i »mjerom « duhovne i materijalne dimenzije, čija autentična »sredina « i stabilnost bića može proizići samo iz onog njegovog najintimnijeg dijela kojeg metaforično i simbolično nazivamo ljudskim srcem. ${ }^{23}$

\section{Dijalektika ljudske osobe}

Hoteći zahvatiti ljudsku stvarnost odozdo, dakle fenomenološkim putem, Guardini, u stilu pristupa koji bi bio više navlastit strukturalnim antropologijama, želi na svoj način ponuditi odgovore na pitanje: što bi to uopće pojam osobe podrazumijevao? ${ }^{24} \mathrm{U}$ strukturnom smislu značenja fenomena i pojma ljudske osobe, naš autor u svojim analizama polazi od onog najbazičnijeg stratuma u čovjeku kao organizirane forme, koja ga čini ukupnim u povezanosti struktura i funkcija, gdje bi ono tjelesno, psihičko i duhovno uopće i moglo u međusobnoj povezanosti »funkcionirati« kao neko jedinstvo. ${ }^{25}$ Individualitet bi bio nešto viši sloj ukoliko bi sugerirao dinamične procese auto-delimitacije i auto-afirmacije sebe. ${ }^{26}$ Kao puka individua čovjek se prije svega pokazuje na bazično-biološkoj razini kao ekscentrično biće koje se nalazi u stalnom pokretu razmjenâ energijâ

21 Usp. Isto, str. 283. Za čovjeka, u vezi s njegovom konkretnom egzistencijom, ne može postojati neki čisti princip tjelesnog ili duhovnog, jer je on upravo sastavljen od jednoga i drugoga. Usp. Romano Guardini, Mondo e persona, Brescia, 2007., 59-69. Interpretirajući Guardinijevo razmišljanje o duhovnom i tjelesnom u čovjeku, teolog Anđelko Domazet primijetio je kako su stoga »neprihvatljiva sva duhovna strujanja koja odnos između duše i tijela vide dualistički tako što taj odnos svode na ‘čisti duh' odnosno ‘duhovnu', ‘unutarnju' pobožnost koja obezvređuje područje tjelesnog. Isto tako, mora se isključiti svaki 'monizam' koji dokida dijalektičku i stvaralačku napetost između duše i tijela«. Anđelko Domazet, Život u dijalogu s Bogom: Teologija i praksa molitve u spisima Romana Guardinia, Zagreb, 2009, 74.

22 Romano Guardini, L'uomo, 282-284.

23 Usp. Isto, 284-285.

24 Čini se kako Guardini na svoj način nudi neku svoju »strukturalnu antropologiju « (to osobito dolazi do izražaja u njegovom već navedenom djelu (Mondo e persona) gdje se govori o strukturi osobe, što bi možda upućivalo na utjecaj Claude Lévi-Straussa i Michela Foucaulta. Usp. Eugen Biser i dr., Romano Guardini e la visione cristiana del mondo, 32-33. Teolog Anđelko Domazet naglasio je kako Guardini u svojim promišljanjima o osobi »dijalogizira s klasičnom filozofijom, ali dobro poznaje i suvremene pravce, pogotovo fenomenologiju i doprinos suvremene filozofske analize u obliku dijaloškog personalizma«. Anđelko Domazet, Život u dijalogu s Bogom, 31.

25 Romano Guardini, Mondo e persona, 135-136.

26 Isto, 136. 
i komunikacije od unutarnjega prema vanjskomu području i obrnuto, nastojeći s jedne strane nadići limitiranost vlastite organsko-biološke centriranosti u proizvodnoj moći preobrazbe vanjskog prirodnog ambijenta u specifičan čovjekov svijet, i s druge strane, iz toga se povratno afirmirati i jačati u oblikovanju vlastite nutrine. Međutim, osobnost kao viši sloj, označuje taj isti individualitet koji bi bio dodatno prožet višom duhovnom dimenzijom svoje duševnosti u ukupnosti onih naravnih sposobnosti koje nazivamo sviješću, što bi sugerirao, dakle, njegov socio-psihološki potencijal bića. Međutim, svi ti prethodni slojevi i moći koji iz toga proizlaze, još ne čine nekoga osobom u pravom smislu riječi, koji postaje to tek u djelatnom pokazivanju samo-svijesti koja si postavlja nešto dublja pitanja tragajući za odgovorom: tko sam zapravo ja? (selbst-verständliche). ${ }^{27}$

Osoba upućuje na neku upravljenost prema višoj vrijednosti sebe u dostojanstvu i duhovnoj sintezi svih svojih prethodnih slojeva, pitajući se, s jedne strane, o smislu sebe i svijeta i, s druge strane, bivajući uvijek zahvaćena onim temeljnim egzistencijalnim pitanjem koje upućuje na misterij života u odnosu na onostrano. Zato za Guardinija koncept i fenomen ljudske osobe ima prije svega teologalni smisao u otvorenosti prema Apsolutu. ${ }^{28}$ Dok čovjek, s jedne strane, nikako ne bi mogao nadići stranputice dijalektičkih spona polarnosti ili slojeva vlastitog bića ako ne bi bio u odnosu s Bogom kao primordijalnom Ti, tek bi to, s druge strane, uvjetovalo bilo koji drugi optimalni društveni odnos prema $t i$ svakog čovjeka. ${ }^{29}$ Zato ukupnost osobe upućuje i na njezin eks-centrično-socijalni karakter koji podrazumijeva neprestano biti-u-odnosu-prema nekomu ili nečemu, kroz stalno izlaženje-iz-sebe, pokazujući se tako ek-statičnom, što pak upućuje da ona ima i teo-logalno obilježje relacije i komunikacije ne samo prema ljudsko-društvenoj nego i božanskoj sferi. ${ }^{30}$

\section{Dijalektika životnog dozrijevanja}

U svom svestranom zanimanju za fenomen čovjeka, naš se autor dotiče i pedagoških tema koje se tiču odgoja, analizirajući na svoj specifičan način i

27 Vjerojatno je tu Guardini bio ponukan slijediti filozofsku nit u prošlosti koja je često gurala u prvi plan važnost samosvijesti mislećeg subjekta, onoga »ja « koji misli i sumnja u kartezijanskom smislu ili Lockeovom isticanju dubokog i izvornog jedinstva ljudskog subjekta, ili u slučaju Hegela, koji govori o neposrednoj svijesti samog sebe. Usp. Albino Babolin, Romano Guardini: Filosofo dell'alterità : Parte prima : Realtà e persona, Bologna, 1968, 244-245.

28 Romano Guardini, Mondo e persona, 173-175.

29 Romano Guardini, Mondo e persona, 173-194. Tu se može nazrijeti utjecaj Martina Bubera, kojega naš autor tu i tamo spominje, a koji razrađuje svoj specifičan dijaloški princip ja-ti u smislu da se čovjek u svojem jastvu može ostvarivati onoliko koliko je otvoren relaciji druge osobe. Buber će za Boga također reći da je vječni-Ti i apsolutni-Ti. Usp. Martin Buber, Il principio dialogico e altri saggi, Milano, ${ }^{2}$ 1993, str. 111. I hrvatski teolog Đuro Zalar u jednom svojem članku dotaknuo se specifikuma Guardinijevog poimanja ljudske osobe u odnošajnosti prema Bogu kao osobi. Usp. Đ uro Zalar, Poimanje milosti u djelu Romana Guardinija, Obnovljeni život, 54/1 (1999), 39-41.

$30 \mathrm{U}$ ovom radu mogao sam se dotaknuti i Guardinijeve razradbe teme odnosa čovjeka kao osobe prema autoritetu i socijalnim relacijama drugoga, također i prema zajednicama kao što su obitelj ili država, u čemu bi također bilo moguće nazrijeti prividno antinomične polove ja-društvo. Međutim, to bi ovdje prelazilo zacrtane norme ukupnog broja dopuštenih stranica pisanoga teksta. 
razvoj ljudske osobe od djetinjstva do starosti. ${ }^{31}$ Životno dozrijevanje već u sebi razotkriva dijalektički karakter u poteškoćama oscilatornih odnosa ja $\leftrightarrow$ društveni svijet, sugerirajući muku uspostave ravnoteže unutar sebe i u odnosu na vanjsku društvenu inter-personalnu stvarnost.

Tako primjerice, već u fazi ranog djetinjstva, mališan koji se doživljava stopljenim s vanjskom stvarnošću, koju želi sve više k sebi prisvajati, ali i u odnosu na nju s vremenom se i diferencirati, u kojoj također otkriva i mnoštvo raznovrsnih i čudnih smislova i značenja, percipira svijet oko sebe na jedan sebi svojski simboličko-mitski način. ${ }^{32} \mathrm{U}$ toj početnoj povezanosti sa svijetom stvari kojima se susreće, potpomognut sigurnošću zbog doživljaja roditeljske blizine, i s time korijenite ovisnosti od drugih što se tiče hranjenja i drugih potreba, dijete prolazi kroz krizu stjecanja vlastitog identiteta nastojeći postići neku vrstu samostalnosti. Tu Guardini primjećuje prvo očitovanje samosvojne ljudske osobnosti koja se tijekom vremena sve više želi razvijati u vidu dva momenta. Prvi bi se odnosio na racionalno stjecanje vlasti nad vanjskom stvarnošću i drugim osobama, i drugi, u buđenju svijesti, kako on navodi, »da bude netko, različit od drugih [...], predstavljajući se kao slobodna i odgovorna osoba, slijedeći vlastiti sud o ovom svijetu i o svojoj poziciji u njemu «.33

U razdoblju pak adolescencije, zbog specifičnih psihosomatskih promjena, nastupa iskustvo dubokih neravnoteža koje osciliraju s jedne strane između doživljenog kaosa u sebi i, s druge, nasuprotne krajnosti u prirodnom idealizmu koji bi sugerirao naivno vjerovanje u automatsku snagu idejâ i namjerâ, s čime bi išla i potreba za raznim radikalizmima. ${ }^{34}$ Učenje uravnotežene osobnosti ide, dakle, zajedno sa stupnjem realistične spoznaje sebe i svijeta oko sebe, što nije tako lako postići ni u kasnijim fazama razvoja. ${ }^{35}$ Po našem autoru, adolescent bi

31 Zanimljivo je dodati kako se neke pedagogijske misli našeg autora slažu s filozofom John Deweyjem. Obojica se zalažu za naglašavanje dimenzije živoga iskustva u razvoju ljudske osobe. Usp. Carlo M. Fedeli, L'educazione come esperienza : Il contributo di John Dewey e Romano Guardini alla pedagogia del Novecento, Rim, 2008, str. 161-171; Romano Guardini, Etica, str. 565-629 i 881-910. Pedagoška je tematika prisutna u mnogim Guardinijevim djelima. Ovdje ćemo navesti samo neka: Ethik. Vorlesungen an den Universität München (1950-1962), Mainz, 1993; Die Begenung, Würzburg, 1955.; Berichte über mein Leben : Autobiographische Aufzeichnungen, Düsseldorf, 1984; Lebendige Freiheit, u: Unterscheidung des Christlichen, Mainz, 1963, str. 82-101; Freiheit und Unabänderlichkeit, u: Unterscheidung des Christlichen, Mainz, 1963, str. 102-120; Lebendiger Geist, u: Unterscheidung des Christlichen, Mainz, 1963, str. 121-144; Die Annahme seiner selbst, Würzburg, 1960; Die Lebensalter : Ihre ethische und pädagogische Bedeutung, Kevelaer, 2010. Na njemačkom o Guardinijevim pedagoškim razmišljanjima osobito vidjeti u: Günter Henner, Die Pädagogik im Denken Romano Guardinis, Paderborn, 1990. Na talijanskom: Anna Ascenzi, Lo spirito dell'educazione : Saggio sulla pedagogia di Romano Guardini, Milano, 2003.

32 Kako u djetetu tada još nema razlikovanja unutarnjeg i vanjskog svijeta, odnosno vlastitih fantazija s percepcijom izvanjske stvarnosti, tu već započinje psihološka dijalektika u muci stjecanja početne autonomije svojeg »ja«. Usp. Romano Guardini, Etica, str. 573-576.

33 Isto, 580.

34 Zbog prividno nasuprotnih tendencija, s jedne strane auto-afirmacije svojega »ja« i s druge strane buđenja seksualnog instinkta, povećava se i ranjivost adolescenta, ako novo nadošli sentimenti ne odgovaraju »perfektnoj slici« samoga sebe. Usp. Isto, 580 i 590.

35 Realistična spoznaja ovisi i o tome koliko je mlada osoba uspostavila vlast nad samom sobom u smislu da posjeduje donekle osjećaj odgovornosti, časti i dužnosti, što pak pridonosi da se odr- 
morao, s jedne strane, biti otvoren učenju subjektivne mjere o svojim objektivnim mogućnostima mimo bilo kakvih idealiziranja i, s druge strane, spoznaji o načinu na koji društveni svijet u svojim poredcima i u međuljudskim odnosima uopće stvarno funkcionira.

Tek u nešto zrelijoj fazi odrasli čovjek trebao bi donekle steći stabilnost osobe koja bi u svojoj autentičnoj mjeri podrazumijevala nekakvu »sigurnost u srži vlastite biti «. ${ }^{36}$ Sve se vrti zapravo oko ključnog momenta osobe, a to je njezin $k a$ rakter, koji sugerira »odlučnost i čvrstoću koja ne znači jednu rigidnost gledišta, nego asocijaciju između mišljenja, sentimenta, vitalne volje i vlastitog duhovnog središta «. ${ }^{37}$ Odrasla osoba se stoga može smatrati zrelom ukoliko ima moć sintetizirati vlastito znanje i sentimente putem djelovanja i realistične percepcije stvarnosti. ${ }^{38}$ Trebalo bi stoga težiti zreloj svijesti, koja bi se odnosila na autentičnu povezanost između »ispravno mišljene ideje « na unutarnjoj mentalnoj razini i također na onoj vanjskoj razini »viđene stvarnosti na pravi način «, kao i između nečije »bezuvjetne nakane« da se na određeni način djeluje, a nasuprot tomu pridolazećemu »osjećaju otpora, komplikacija i bijede stvarnosti«.39

\section{Dijalektika kreposti}

Osobito u sadašnje post-moderno vrijeme u kojem čovjek kuša veliku krizu vlastitog identiteta, naš se autor zalaže upravo za renesansu kreposti zbog nastojanja za mogućom njegovom re-personalizacijom, odnosno autentičnom obnovom kao cjelovite osobe. ${ }^{40}$ Tako bi kreposti istinitosti i prihvaćanja kroz jedan unutarnji stav otvorenosti trebale sugerirati prvi uvjet za bilo kakvu moguću

žava unutarnji ekvilibrij osobnosti, a nasuprot opasnosti da se destabilizira i raspline u mnoštvu vanjskih utjecaja. Usp. Isto, 581-582.

36 Isto, 604. Muškarac ili žena i u tzv. »srednjoj« ili »odrasloj« dobi nisu počesto lišeni doživljaja tjeskobe i potištenosti zbog iskustva bezličnosti svakodnevne rutinizirane stvarnosti. I sâm se Guardini pita: kako im se zapravo može pomoći? Usp. Romano Guardini, Etica, 606-611. U jednom svojem manjem spisu $O$ smislu potištenosti, dotaknuo se i te problematike ljudske egzistencije, što osobito na iscrpan način analizira i teolog Anđelko Domazet. Usp. Anđelko Domazet, Smisao potištenosti prema Romanu Guardiniju, Služba Božja, 51/2 (2011), 205-216.

37 Romano Guardini, Etica, 604.

38 Za Guardinia, zrela bi osoba podrazumijevala »onu harmoniju, onu intenzivnost, onu senzibilnost koje se ostvaruju u čovjeku ukoliko on ima spoznaju sebe i sposoban je razlikovati se od drugih ljudi, ukoliko slobodno preuzima odgovornost za svoje čine, ukoliko je u bitnom odnosu s apsolutnim vrijednostima koje on mora ostvarivati među ljudima i stvarima«. Romano Guardini, L'esistenza del cristiano, Milano, 1985, str. 110-111.

39 Romano Guardini, Etica, str. 607. Treba dodati kako se Guardinijeva analiza razvoja i dozrijevanja čovjeka gotovo slaže s općim psihologijskim i pedagogijskim uvidima o tom području. Usp. Antonio Arto - Marco Piccino - Elisabetta Serra, La ricchezza umana in crescita: Fondamenti di psicologia dell'arco della vita, Rim, 2010, str. 149-173.

40 Guardinijev koncept kreposti biva inspiriran Platonovim pristupom, gdje ono kreposno ima otvoriti put spoznaji i praksi Dobroga. U kršćanskom smislu ono najviše Dobro jest Bog kao konačni razlog i smisao kreposnog života, što naš autor posebno naglašava. Međutim, njegov opis pojedinih kreposti (ovdje ću uzeti samo neke koje on navodi u svojem djelu Virtù) mimo kakvih god pretjeranih moraliziranja, obiluje praktičnim jezikom mudrosti, spuštajući svoju refleksiju 
pozitivnu promjenu u smislu dozrijevanja svojega »ja «. ${ }^{41}$ Te bi kreposti upućivale na nešto što se možda na prvi pogled čini lakim, ali je u stvarnosti teško postići u smislu nastojanja za uspostavom nužnog kontakta-sa-stvarnošću, onakvom već kako se ona pred nama pred-meće u svojim objektivnim biološkim, psihološkim i društvenim očiglednostima, kao i, s druge strane, na prihvaćanje sfere Duha s kojim se tek razumijeva istina na jednoj dubljoj razini smisla, gdje se otkrivaju odgovori koji osvjetljuju pravo značenje stvari. ${ }^{42}$ Prihvatiti istinu o sebi i onu koja se odnosi na korektno razumijevanje stvari oko sebe ne čini se, dakle, nimalo lakim zadatkom, jer je ljudska svijest toliko pomućena utjecajima raznih perceptivnih i intelektualnih iskrivljavanja koja dolaze od javnih medija, časopisa, politike itd. ${ }^{43}$

Međutim, tek se s krepošću hrabrosti mogu mobilizirati unutarnje snage bića u konkretnom suočavanju s vanjskim životnim poteškoćama, kao i pružati otpor unutarnjim opasnostima koje bi vodile vlastitoj pasivizaciji i nekomu ovisničkomu ropstvu bića. ${ }^{44}$ Ništa se ne može promijeniti ili pokrenuti u čovjeku ako se nema nikakve smjelosti izići iz komforne zone svoga »ja«, koje se uglavnom kreće po već utabanim rutinama navikâ. Upravo hrabrost upućuje na bit osobe koja znači izići-iz-samoga-sebe, transcendirati ono nisko u sebi koje čovjeka zarobljava i naposljetku biti otvoren spoznaji da smo u svojoj jezgri zapravo duhovna bića.

Dok bi taj stav hrabrosti u čovjeku predstavljao inicijalni motivacijski impuls da se u njemu nešto pokrene, s askezom se događa naprotiv konkretna praksa s kojom se nastoji nadići ona organsko-nagonska pasivnost u opasnosti samozatvaranja sebe u puko tjelesno-senzitivno područje, ili pak steći konkretne sposobnosti odupiranja vanjskim opasnostima s kojima se može izgubiti vlastiti integritet. Za razliku od područnih ili instrumentalnih askeza u vidu vojne ili radne discipline ili onih suviše iscrpljujućih u primjeru zen-budizma, Guardini se zalaže za onu vrstu samonadzora koja bi čovjeku priskrbila unutarnju ravnotežu kao uvjeta auto-percepcije »ja« kao stabilne osobe i pružala mu sposobnost kušanja područja Duha. ${ }^{45}$

Socijalnim krepostima poput poštovanja i ljubaznosti želi se pak potaknuti topla društvena relacionalnost ja-ti, nasuprot hladnoći mehanizacije i rutinizacije međuljudskih odnosa koji su često motivirani funkcionalizmom nekog institucionalnog aparata ili nekom vrstom egoistično-interesno-proračunatog ponašanja, koje drugog želi svesti na neko puko iskoristivo sredstvo cilja. ${ }^{46}$ Poštovanje ide za tim da drugomu prizna dostojanstvo, navlastitost i vrijednost kao osobi, zbog

na jednu antropološku razinu. Usp. Romano Guardini, Virtù : Temi e prospettive della vita morale, Brescia, 2008.

41 Usp. Isto, 21-44.

42 Za našeg autora, otvorenost istini ili svojstvu istinoljubivosti morala bi po sebi voditi Bogu kao neospornoj istini. Usp. Isto, 29-32.

43 Usp. Isto, 30.

44 Usp. Isto, 109-121.

45 Usp. Isto, 97-108. Sažetu razradbu Guardinijeva razumijevanja askeze vidi također u: Anđelko Domazet, Život u dijalogu s Bogom, 103-105.

46 Usp. Romano Guardini, Virtù, 67-78 i 143-156. 
čega se u toj pozitivnoj socijalnoj atmosferi i mi afirmiramo kao osobno-dostojanstvena bića. Ljubaznošću se pak na konkretan način odašilje to poštovanje, nasuprot agresivnomu nametanju ili dominaciji nad drugim.

Krepostima sabranosti i šutnje sugerira se pak povratak čovjeka njemu samomu u ponovnom otkrivanju onog njegovog unutarnjeg živog središta sebe, o čemu uvelike ovisi njegova svekolika stabilizacija i harmonizacija. ${ }^{47}$ Današnji je čovjek u najvećoj mjeri otuđen od samog sebe jer je njegovo biće posve eksternalizirano, toliko rasplinuto u vanjštinu aktivnosti, uloga, statusa i zadataka, gdje se zbrajaju samo vanjski učinci, na temelju čega ga se potom vrednuje. Sabranost predstavlja onaj inicijalni napor prema šutnji, po kojoj se stječe nova kvaliteta spoznaje svojega »ja«, gdje se ponešto i može kušati ono unutarnje duhovno iskustvo cjelovitosti sebe, koje sluti na nešto izvan sebe, na Boga i područje svetog, kao u konačnici najkvalificiranijeg mjesta čovjekove realizacije kao autentične osobe. ${ }^{48}$

\section{Zaključak}

Očito je kako nam Guardini nudi jednu posve dinamičko-dijalektičku sliku čovjeka, koji je kao duševno-tjelesno, osobno i društveno biće stalno uvučen u procese interakcije svakovrsnih polarnih suprotnosti vlastite ili općenite zbilje kao životnog ambijenta, u kojem se odvija njegova egzistencija. Kako svekolika fizikalno-biološka stvarnost na neki način uvijek oscilira u nekim suprotnostima i napetostima, u najosnovnijem smislu rečeno, između dinamičnosti nekog čina i pokretnosti s jedne te smjeranju u stabilizaciji u nekoj formi i strukturi s druge strane, koliko se pak još više čovjeku nameće pomalo mučan zahtjev da za sebe samog nađe neku unutarnju i vanjsku »mjeru« $\mathrm{i} »$ ritam « osobne »stabilnosti i »sređenosti« vlastitoga »ja«.

Već u svojem promišljanju o odnosu duševnog i tjelesnog u čovjeku, Guardini skreće pozornost na opasnosti koje bi upućivale na kakvu god životno-praktičnu sklonost po kojoj bi se želio neki pojedinac, makar i u nakani, rasplinuti u isključivo duhovno ili materijalno područje svojega »ja«, što bi rezultiralo njegovom dezintegracijom odnosno »raz-osobljenjem «. Stoga nitko u sebi ne bi ni mogao postići takvo vlastito stanje »čiste spiritualnosti « ili »čiste tjelesnosti $u$ u smislu da bi jedan aspekt u nekom zamišljenom monističkom smislu jednostavno asimilirao onaj drugi nasuprotni, kako je to već bilo u povijesti prisutno u primjerima strogo asketsko-duhovnih sustava, kojima se je potcjenjivalo tijelo, ili danas obrnuto, kada se hedonistički egzaltira na kultni način tjelesnost.

I u jednoj i u drugoj krajnosti gubi se naime ona temeljna prirođena sposobnost da čovjek sebe gleda i samo-doživljava kao cjelovito biće (Gestalt), bez čega nije o njemu moguće govoriti kao osobi (Person) u pravom smislu te riječi. Osoba

47 Usp. Isto, 181-208.

48 Za Guardinija pritom nema ni estetske kontemplacije, ni dijaloga, ni mudrosne spoznaje bez vježbanja u unutarnjoj šutnji. Usp. Silvano Zucal, Romano Guardini, filosofo del silenzio, Città del Castello, 1992, str. 13. Usp. Anđelko Domazet, Život u dijalogu s Bogom, 112-120. 
zato implicira neku cjelovitost, jedinstvo, specifičnu navlastitost i samo-pripadnost, sintezu, nipošto onu Hegelovu u kojoj bi se dokinuli ili nadišli polovi teze i antiteze, nego je ovdje riječ o nalaženju ritma i mjere u napetostima samostojećih suprotnih dimenzija koje ostaju kao takve u svim svojim egzistencijalnim mogućnostima. Netko stoga postaje utoliko »više « osoba koliko se uspijeva harmonizirati, uravnotežiti, odnosno uskladiti u koordinatama onog sebi vlastitog unutarnjeg i vanjskog, individualnog i društvenog, tjelesnog i duhovnog. Za tako nešto potreban je odgoj (Bildung) koji bi omogućio rast i razvoj svih dimenzija ljudske naravi, bioloških, psiholoških i socijalnih. Odgoj pak nije moguć bez vrijednosti koje bi ljudskomu dozrijevanju podarile smisao, smjer i motivaciju.

U suvremenosti tzv. postmoderne svjedoci smo marginaliziranja onih vrijednosti koje bi bile onkraj individualističkog, utilitarističkog ili hedonističkog, zbog čega suvremeni čovjek zapravo kuša veliku krizu samoprepoznavanja sebe kao cjelovitog bića. I njegova je relacionalnost, odnosno društvenost, također u krizi s obzirom na prevladavajuće okolnosti narcističkog i surovog konkurentskog mentaliteta, gdje se drugog gleda kao puko sredstvo interesa. Zbog toga bi po Guardiniju trebalo iznova progovoriti o krepostima koje kao duhovne vrijednosti predstavljaju konkretne smjernice istinskoj obnovi čovjeka kao osobe u svim svojim tjelesnim, društvenim i duhovnim dimenzijama.

\section{Reflections on Man as a Creature of Dynamic-Dialectical Tension in Some} Works of Romano Guardini

Davor Šimunec*

\section{Summary}

The essay strives to cast a light on the specificity of Guardini's dialectical reasoning involving man whom he understands as a being whose maturation or authentic self-realization occurs insofar as the oscillations of polarity are achieved through the spiritual and corporeal internal-individual and external-social dimensions of his self in adequate measure. With the aim of discovering the dialectical thread that runs through all principal dimensions of the »I «, the beginning of the essay describes the manner in which Guardini sees the dialectical structure of reality. The author continues by seeking to make tangible the same dialecticity in examples pertaining to the »structure " of man and his individual-social-developmental capacities. Thus, polar moments are elaborated in regard to the relationship between the soul and the body, the strata of being, and briefly also the developmental dynamics of human maturation from childhood to adulthood. Finally, virtues are discussed as spiritual values which may direct the course of development of those capabilities which, on the one hand, would make possible man's internal and external equilibrium, and on the other hand, an openness toward the Absolute.

Key words: dialectic, polar opposition, soul, body, person, personality maturation, virtues

* Davor Šimunec, Ph.D., The Catholic Faculty of Theology at the University of Zagreb. Address: Vlaška 38, p.p. 432, 10001 Zagreb, Croatia.E-mail: dav.simun@gmail.com 